\title{
Factors Affecting Profitability of Banks: Empirical Evidence from Ethiopian Private Commercial Banks
}

\author{
Yalemselam Worku Bogale \\ Department of Accounting and Finance, Debre Berhan University, Debre Berhan, Ethiopia \\ Email Address: \\ yalemselam12@gmail.com

\section{To cite this article:} \\ Yalemselam Worku Bogale. Factors Affecting Profitability of Banks: Empirical Evidence from Ethiopian Private Commercial Banks. Journal \\ of Investment and Management. Vol. 8, No. 1, 2019, pp. 8-15. doi: 10.11648/j.jim.20190801.12
}

Received: December 24, 2018; Accepted: January 20, 2019; Published: January 31, 2019

\begin{abstract}
The objective of this study was investigating factors affecting the profitability of private commercial banks in Ethiopia, covering ten years period from 2008 to 2017, using unbalanced panel data from fourteen Ethiopian private commercial banks. In this study, survey was used as a method of a research design, which allows collecting quantitative data that was analyzed quantitatively using STATA 13 software. The variables covered under this study were both bank specific factors (capital adequacy, bank size, liquidity risk, credit risk, and operation efficiency) and macroeconomic factors (real GDP growth rate, inflation, foreign exchange rate, and lending interest rate). The fixed effect regression output revealed that from bank specific variables; capital adequacy and bank size have significant positive effect on profitability. Besides, operation efficiency has a negative significant effect on profitability, but liquidity risk and credit risk were found not powerful variables in the determination of banks profitability. From macroeconomic variables; foreign exchange rate and lending interest rate were found to have significant (though at $10 \%$ level of significance) negative effect on Ethiopian private commercial banks profitability. Conversely, real GDP growth rate and inflation rate were found statistically insignificant. Generally, in this study bank specific factors have more significant effect than macroeconomic factors. So, private commercial banks in Ethiopia were suggested to increase their stockholders equity, asset size and implement an effective and efficient expense management practice in order to boost their profitability.
\end{abstract}

Keywords: Bank Specific and Macroeconomic Factors, Profitability, Private Commercial Banks, Ethiopia

\section{Introduction}

\subsection{Background of the Study}

A bank is commonly recognized as an institution which provides fundamental banking services such as accepting deposits and providing loans [1]. It is observable that commercial banks play a vital role in the economic development of a country. Banks accumulate the idle savings of the people and make them available for investment that means banks serve as intimidator between saver and investor [17].

If the banking sector does not perform in a good health, the consequence to the economy could be enormous and wide. Due to the U.S. sub-prime mortgage crisis that happened in recent times, the banking sectors of many countries suffer huge losses, especially in U.S. and E.U. The poor performance of the banking industry has slowed down the U.S. economy and also the development of global economy until the current period. In Asia, although the losses in banking sectors are not as serious as U.S., it is also have a significant adverse impact on their economy [25]. Thus, financial institutions must be profitable in order to ensure the stability of the financial system as well as the overall economy.

During the last two decades, the banking sector in Africa and in the rest of the developing countries has experienced major transformation in its working environment. In a number of countries, financial sector reforms have been executed. In these reforms, the role of commercial banks has remained central in financing economic activities in the various parts of the markets especially in Sub-Saharan Africa [1].

Profitability for African banks can only be attained if bank managers and policy makers continue to pay serious attention 
to internal (bank specific) as well as external (macroeconomic) factors that have an effect on their profitability [11]. Given the lower profitability from corner to corner commercial banks since recent period, it would be important to implement second generation reforms of the banking sector to bring about the desired growth performance of the industry.

Banks in Ethiopia, particularly private banks, turn out to be profitable every year, have made good returns to their shareholders or investors. This has helped them to get more funds from the public and enhance their capital buffers, and remain solvent but there are variations on private banks financial performances. Therefore, banks' profitability will generally vary directly with the riskiness of their portfolios and operations, they need always to carefully identify, assess, monitor and control risks associated with credit, liquidity, market, operations, reputation, legality and the overall economic environment [10].

In general, bank profitability studies are unquestionably desired because, commercial banks not profitable means the entire economy may become unstable and will be adversely affected since banks play a prominent role in the economic development of a country. So, this study covered variables both bank specific and macroeconomic factors to examine their effect on the profitability of private commercial banks which exist in Ethiopia.

\subsection{Statement of the Problem}

Profitability is an indispensable for a bank to maintain ongoing activity and for its shareholders to obtain fair returns and wealth maximization. Similarly, it is also vital for supervisors because it guarantees more flexible capital ratios, even in the situation of a riskier business environment [22]. The study of banks profitability is important not only for that of the information it provides about the wellbeing of the economy in any given year, but also because obviously it is a key determinant of growth, employment and the overall development of a given country [1].

A number of studies were conducted across the world regarding factors affecting banks profitability. However, their findings were different across country, bank nature and ownership structure. For instance, a study conducted in the US banking industry with the aim of identifing determinants of banks profitability revealed that bank size has a negative and significant effect on profitability [15]. In contrast, a study entitled determinants of bank profitability in Ukraine found that bank size has a positive relationship with bank profitability [7]. Moreover, the result of the study which is aimed to identify factors impacting profitability of commercial banks in Pakistan shows bank size and profitability has no relationship at all [8]. Similarly, the results for other variables were not unique. The reason for the dissimilarity of results is that there are no steady determinants for bank profitability because of continuous change in globalization, deregulation, parallel competition from the non-banking financial institutions and volatile market dynamics.
Therefore, investigation on factors affecting banks profitability is open for empirical analysis to researchers, bank managements, financial market analysts and regulators in the past and also will be equally important in the future [16].

In case of Ethiopia, there are few (finger counted) studies undertaken related to factors affecting banks profitability [1, 9, 14, 12, 17, 23]. However, the variables incorporated and examined in their studies do not include many relevant variables that are widely mentioned in the existing literatures, which are key determinants of banks profitability. Moreover, most of them tried to investigate the determinants of banks profitability with data of limited number of banks and years.

Considering this gap, this study was designed to investigate major factors affecting profitability of Ethiopian private commercial banks directly from a wide range of variables in an objective manner and through significant measurement of profitability.

\subsection{Objectives of the Study}

\subsubsection{General Objective}

The main objective of this study was investigating factors affecting the profitability of Ethiopian private commercial banks.

\subsubsection{Specific Objectives}

a). To identify the effects of bank specific factors (capital adequacy, bank size, liquidity risk, credit risk, and operation efficiency) on Ethiopian private commercial banks profitability.

b). To assess the impact of external factors (real GDP growth rate, inflation, foreign exchange rate and lending interest rate) on Ethiopian private commercial banks profitability.

\section{Review of Related Literatures}

This study aims to fill the gap in the existing literature by identifying the factors affecting profitability of banks. This section of the study reviews previous literatures in banks profitability determinants. More specifically, this section provides the definition and measurements of banks profitability first. Then, reviews of empirical literatures on factors affecting banks profitability are presented.

\subsection{Definition and Measurements of Banks Profitability}

Net income, more commonly referred to as profits after taxes, is the figure that tells most directly how well the bank is doing because it is the amount that the bank has available to keep as retained earnings or to pay out to stockholders as dividends. Although net income gives an idea of how well a bank is doing, it suffers from one major drawback: it does not adjust for the bank's size, thus making it hard to compare how well one bank is doing relative to another.

There are different profitability ratios like Return on Asset (ROA), Return on Equity (ROE) and Net Interest Margin (NIM) [19]. A basic measure of bank profitability that 
corrects for the size of the bank is ROA. The dependant variable in the model specified is a measure of private commercial banks profitability. In line with earlier studies on commercial banks profitability, ROA ratio was used in this study as a measure of banks profitability.

\subsection{Factors Affecting Banks Profitability}

According to previous studies, the factors affecting profitability of banks are divided into two main categories; bank specific and macroeconomic factors. Bank specific factors are unique to individual banks such as capital adequacy, bank size, liquidity risk, credit risk, operation efficiency and others. Moreover, profitability of banks also highly influenced by macroeconomic conditions such as real GDP growth rate, inflation, and foreign exchange rate and lending interest rate and others.

A study conducted to assess the determinants of profitability on fifteen Nigerian banks by gathering ten years panel data of the bank's financial statements showed that increase in size (higher total assets) may not necessarily lead to higher profits due to diseconomies of scale; higher capitalassets ratio and loans and advances contribute strongly to bank profitability [2].

Under their study which is conducted on United Kingdom owned commercial banks researchers found that capital adequacy of banks has a positive and significant influence on their profitability, the other important factors are being efficient in expenses management and bank size [18].

In their study entitled bank specific, industry specific and macroeconomic determinants of bank profitability researchers apply a GMM technique to a panel of Greece banks that covers the period from 1985 to 2001 . The estimation result display that profitability persists to a slight volume, indicating that departures from perfectly competitive marketplace structures may not be that much large. All bank-specific determinants, except size, affect financial institution profitability extensively. However, no proof is located in guide of the hypothesis. Subsequently, the business cycle has a tremendous, even though uneven impact on banks profitability, being large handiest in the top phase of the cycle [3].

A researcher examines the profitability determinants of commercial banks in Greece and Balkans, by collecting an unbalanced panel data of 115 commercial banks over a period of six years. He found that bank size and capital adequacy have a positive effect on commercial banks. However, the variable of bank size is statistically significant only for the crisis period, whereas capital adequacy is significant in both periods. Concerning the macroeconomic variables, only real GDP is significant during financial crisis. It appears to have a positive relationship with ROA, for the pre-crisis period, though it has a negative one for the crisis/post-crisis period [27].

A study on profitability determinants of Indian banks has been conducted using ten years' data that put forward some most important conclusions which can be useful to the practical banking world. The regression outcome imply that factors like yield on advances, total deposits to total liabilities and employee cost to total expenses turned out to be most significant [6].
Under their study entitled an empirical analysis of the determinants of bank profitability in Romania researchers proposed to investigate the factors that have an effect upon the profitability of Romanian commercial banks, for the period from 2003 to 2011. The result of this study proves that Romanian banks' profitability is influenced by both internal factors and changes in the overall economy. In the case of internal factors, the result reflect that bank profitability is significantly influenced by asset quality, management quality and banking liquidity. Among macroeconomic factors, the result depict that banking concentration and economic growth rate have a significant impact on banks profitability [24].

\section{Research Methodology}

\subsection{Research Design}

In order to achieve the objectives of the study the researcher used survey as a method of research design. The survey strategy allows the researcher to collect quantitative data which was analyzed quantitatively.

\subsection{Data Type and Sources}

The study used secondary data only. The data have the characteristics of both cross sectional and time series data; this is why the researcher used a panel data approach. Data for the study was collected from National Bank of Ethiopia annual reports and from individual banks audited financial statements in their website and branches.

\subsection{Population, Sampling Design and Sample Size}

Population: The population of this study is sixteen Ethiopian private commercial banks. Namely; Awash International Bank (AIB), Dashen Bank (DB), Bank of Abyssinia (BOA), Wegagen Bank (WB), United Bank (UB), Nib International Bank (NIB), Cooperative Bank of Oromia (CBO), Lion International Bank (LIB), Oromia International Bank (OIB), Zemen Bank (ZB), Bunna International Bank (BUIB), Birhan International Bank (BIB), Abay Bank (AB), Addis International Bank (ADIB), Debub Global Bank (DGB) and Enat Bank (EB) [20].

Sampling Design and Sample Size: The sampling technique used under this study was purposive sampling. In this study fourteen Ethiopian privet commercial banks were incorporated those are AIB, DB, BOA, WB, UB, NIB, CBO, LIB, OIB, ZB, BUIB, BIB, AB, ADIB and the time period covers from 2008 to 2017 . For the reason that the rest two commercial banks are established recently and were not have full data they are excluded from the sample. In addition, it is also possible to draw a relationship among variables by $87.5 \%$ of the population, which means it is highly representative.

\subsection{Operational Definitions of Variables}

Operational definitions of the dependent and explanatory variables incorporated in this study are presented in the following manner. 
Table 1. Variables, their Operational Definitions and Notations.

\begin{tabular}{lll}
\hline Notations & Variables & Operational Definitions \\
\hline ROA & Profitability & Net Income after Tax /Total Assets \\
CA & Capital Adequacy & Total Capital/Total Assets \\
BS & Bank Size & Natural Logarithm of Total Assets \\
LR & Liquidity Risk & Total Loan/ Total Deposit \\
CR & Credit Risk & Loan Loss Provisions/Total Loans \\
OPE & Operating Efficiency & Total Cost/ Total Income \\
LIR & Lending Interest Rate & Annual Average Lending Interest Rate \\
INF & Inflation & Annual Rate of Inflation of the country \\
RGDPGR & Real GDP Growth Rate & Real GDP Growth Rate of the country \\
FER & Foreign Exchange Rate & Annual weighted average rate with reciprocal value \\
\hline
\end{tabular}

\subsection{Model Specification}

The study covers one dependent variable and nine explanatory variables. Thus, the model is a multiple linear regression model. In order to choose the suitable econometric model (i.e. either fixed effect or random effect) hausman specification test was carried out. For this data the following panel models are developed.

Fixed effect:

$$
R O A_{i t}=\alpha_{i}+\beta_{1} C A_{i t}+\beta_{2} B S_{i t}+\beta_{3} L R_{i t}+\beta_{4} C R_{i t}+\beta_{5} O P E_{i t}+\beta_{6} G D P_{i t}+\beta_{7} I N F_{i t}+\beta_{8} I R_{i t}+\beta_{9} F E R_{i t}+\varepsilon_{i t}
$$

Random effect:

$$
R O A_{i t}=\alpha_{i}+\beta_{1} C A_{i t}+\beta_{2} B S_{i t}+\beta_{3} L R_{i t}+\beta_{4} C R_{i t}+\beta_{5} O P E_{i t}+\beta_{6} G D P_{i t}+\beta_{7} I N F_{i t}+\beta_{8} I R_{i t}+\beta_{9} F E R_{i t}+\varepsilon_{i t}+u_{i}
$$

If so, the model will be:

$$
R O A_{i t}=\alpha_{i}+\beta_{1} C A_{i t}+\beta_{2} B S_{i t}+\beta_{3} L R_{i t}+\beta_{4} C R_{i t}+\beta_{5} O P E_{i t}+\beta_{6} G D P_{i t}+\beta_{7} I N F_{i t}+\beta_{8} I R_{i t}+\beta_{9} F E R_{i t}+Y_{i t}
$$

Where,

ROA = Return on Asset

$\mathrm{CA}=$ Capital Adequacy

$\mathrm{BS}=$ Bank Size

LR $=$ Liquidity Risk

$\mathrm{CR}=$ Credit Risk

OPE $=$ Operation Efficiency

GDP $=$ Gross Domestic Product

$\mathrm{INF}=$ Inflation

$\mathrm{IR}=$ Interest Rate

$\mathrm{FER}=$ Foreign Exchange Rate

$\mathrm{i}=$ Entity

$\alpha=$ Intercept

$\beta_{1-} \beta_{9}=$ Coefficients of explanatory variables

$\varepsilon=$ Error term

$\mathrm{u}=$ Random effect of individual bank

$\mathrm{Y}=$ Composite error term

\section{Result and Discussion}

\subsection{Regression Diagnostic Tests}

Before going to the result of fixed and/or random effect model regression analysis part it is must to make sure that the panel data and model fit with classical linear regression model (CLRM) assumptions.

\subsubsection{Normality Test}

One of the CLRM assumption is that zero mean value of the error term. In order to test the normality of the data, Shapiro-Wilk W test for normal data is used. Shapiro Wilk W test for normal distribution is appropriate for small samples from $4 \leq \mathrm{n} \leq 2000$ [5]. According to Shapiro-Wilk W test for normal data the data is not normal if the $p$ value is less than 0.05 . If $p$ value is greater than 0.05 the null hypothesis that states the error term of the model is normally distributed will be accepted.

Table 2. Shapiro-Wilk W Test for Normal Data.

\begin{tabular}{llllll}
\hline \multicolumn{6}{l}{ Shapiro-Wilk W test for normal data } \\
\hline Variable & Obs. & W & V & Z & Prob. $>$ z \\
\hline Residual & 121 & 0.98476 & 1.477 & 0.874 & 0.19117 \\
\hline
\end{tabular}

Source: STATA 13 output for Test of Normality of Data.

According to Shapiro-Wilk W test for normal data the error term is normally distributed since $p$ value 0.19 which is above 0.05 . In this case we have enough evidence to say error term of the model is normally distributed.

\subsubsection{Multicollinearity Test}

Pearson correlation matrix was used for identifying the multicollinearity problem; a highest relationship between the explanatory variables. All the variables of this study were with a correlation coefficient below 0.8 , even below 0.70 which is acceptable. The test result was shown in the appendix part under table 4. Moreover, the mean variance inflation factor (VIF) calculated for the model is 1.86 which is less than 10 and $1 / \mathrm{VIF}$ which is tolerance level is more than 0.10 for all explanatory variables of the study. These tests confirm the presence of lower degree of co linearity among the explanatory variables. 


\subsubsection{Heteroskedasticity Test}

Heteroskedasticity is the variances of the error term, given the explanatory variables are not constant [28]. For this study Breusch-Pagan test, a test for heteroskedasticity, where the squared residuals are regressed on the explanatory variables in the model is used. According to this test, if the test statistic has a p-value below an appropriate significant level (0.05) then the null hypothesis of homoskedasticity is rejected and heteroskedasticity is assumed. On the other hand if p-value is greater than 0.05 , homoskedasticity is assumed.

STATA 13 output for heteroskedasticity test in this study revealed that the value of $\mathrm{p}$ is 0.2626 , which is quite higher than the standard that is 0.05 . So, it can be concluded that there is no heteroskedasticity that means the squared residual is not correlated with explanatory variables (homoskedastic) or the variance for error term is constant.

\subsubsection{Autocorrelation Test}

The Durbin-Watson d statistics was used for testing autocorrelation between error variances. From DurbinWatson d statistics table for $\mathrm{n}=121$ observations and $\mathrm{k}=9$ number of explanatory variables was taken at $5 \%$ level of significance, critical value for $\mathrm{d}_{\mathrm{L}}$ and $\mathrm{d}_{\mathrm{U}}$ was 1.442 and 1.903 respectively. According to STATA the DW calculated value became 1.744. This value is in between the upper and lower bounds, which is inconclusive so there is no correlation of residuals in this study.

\subsection{Fixed Versus Random Effect Model}

The collected data were estimated based on a panel model, which includes cross sectional and time series observations for fourteen commercial banks that ranges over 2008 to 2017. The commonly used models for panel data are fixed effects and random effects models. In order to employ either fixed or random effect model a formal test so called hausman test is used.

Hausman test is based on the null hypothesis in favor of random effect model estimator. If $p$ value is higher than 0.05 (insignificant) random effects is preferable and if $p$ value is lower than 0.05 (significant) fixed effect is preferable [13]. According to hausman test, shown in the appendix part under table 5 , the model is better off if fixed effect model is used since the $\mathrm{p}$ value for the model 0.0000 , which is less than 0.05 (significant).

\subsection{Regression Result and Discussion}

\subsubsection{Regression Result}

Table 3. Fixed Effect Regression Result.

\begin{tabular}{|c|c|c|c|c|c|c|}
\hline \multicolumn{7}{|c|}{ Fixed Effect Regression Result } \\
\hline ROA & Coef. & Robust Std. Err & t & $\mathbf{P}>|\mathbf{t}|$ & {$[95 \%$ Con } & \\
\hline $\mathrm{CA}$ & .3117226 & .108638 & 2.87 & $0.005 *$ & .0961339 & .5273112 \\
\hline BS & 1.39825 & 6099333 & 2.29 & $0.024 * *$ & .1878572 & 2.608643 \\
\hline LR & .2209723 & 1531969 & 1.44 & 0.152 & -.0830419 & .5249866 \\
\hline $\mathrm{CR}$ & .0351296 & .0260507 & 1.35 & 0.181 & -.0165672 & .0868264 \\
\hline OPE & -1.616984 & .1088395 & -14.86 & $0.000 *$ & -1.832972 & -1.400995 \\
\hline LIR & -.7189293 & .4109205 & -1.75 & $0.083 * * *$ & -1.534388 & .096529 \\
\hline RGDPGR & -.0224091 & .16412 & -0.14 & 0.892 & -.3481 & .3032818 \\
\hline FER & -.1762523 & .0914451 & -1.93 & $0.057 * * *$ & -.3577222 & .0052176 \\
\hline Cons & -9.997763 & 1.95469 & -5.11 & 0.000 & -13.87678 & -6.118744 \\
\hline
\end{tabular}

Model: Fixed-Effects (within) regression R-sq: within $=0.7691$ between $=0.6833$ overall $=0.7442$.

No. Obs. $=121$

$\mathrm{F}(9,98)=36.27$

Prob $>\mathrm{F}=.0 .0000$

Note: $* * *$ and $* * *$ shows significant at $1 \%, 5 \%$ and $10 \%$ level of significance respectively.

Source: STATA 13 output for fixed effect regression analyses.

\subsubsection{Discussion}

As seen from the above table the fixed-effects (within) regression is conducted for unbalanced data set with 121 observations, which is collected from fourteen Ethiopian private commercial banks from 2008 to 2017 with a minimum year taken (five years) for recently established banks and a maximum year (ten years) for early established banks. The result have 0.7691 within $\mathrm{R}$ square value, which shows about $77 \%$ of variation in the dependant variable is due to explanatory variables included in this study and the remaining $23 \%$ variation is due to unobserved variables or error term.

\section{Capital Adequacy}

Capital adequacy is found significant explanatory variable at $1 \%$ significant level with $\mathrm{p}$ value of 0.005 , which has a positive relationship with banks profitability. This result is similar with other researchers who found a positive significant relationship between capital adequacy and banks profitability [2, 26, 21, 14]. The coefficient of capital adequacy 0.3117226 indicates remaining other variables constant a one percent change in capital adequacy will result around 0.3 percent change in banks profitability.

Given that the relationship between banks profitability and banks capital adequacy ratio is positive and highly significant, increasing paid up share capital and banks 
retained earnings will increase profitability of banks. This is for the reason that banks with higher capital adequacy ratio can attain an efficient intermediation practice, engage in prudent lending, in addition to this they are able to minimize their funding cost because large share of capital is a key gauge of creditworthiness.

\section{Bank Size}

Bank size is significant and positively related with Ethiopian private commercial banks profitability at 5\% significant level with a $\mathrm{p}$ value of 0.024 . The coefficient of bank size 1.39825 shows holding other variables constant a one percent change in bank size will have about 1.4 percent change in Ethiopian private commercial banks profitability.

The result of this study is consistence with the result of other researchers who found a significant positive relationship between bank size and profitability $[27,26,21$, 14].

\section{Operation Efficiency}

Operation efficiency is found highly significant in the determination of Ethiopian private commercial banks profitability at $1 \%$ significant level with a $p$ value of 0.000 . The coefficient of operation efficiency is negative 1.616984 . This tells a change in one percent of operation efficiency will have an effect to a change in ROA in negative 1.616984. So, it is possible to say that banks with high expense management (low level of operation efficiency ratio) will generate higher profit.

In regard to this variable, a researcher on determinants of commercial bank profitability found that the coefficient of the ratio of cost to income, which provides information on the efficiency of the company expenses relative to income, was negative and statistically significant [26]. Similarly, a study on determinants of banks profitability conducted in Tunisia concludes that the operating efficiency variable is statistically significant and negatively related to the profitability for commercial banks [4].

In a nutshell, this result is consistence with the early expectation of the researcher. Compared to other explanatory variables, either it may be bank specific or macroeconomic factors considered in this study, operation efficiency is out to be most important predictors with a lowest $p$ value of 0.000 to Ethiopian private commercial banks profitability. Thus, giving high consideration for expense management is vital to be profitable in the banking industry in Ethiopia.

Lending Interest Rate

Lending interest rate is statistically significant with $p$ value of 0.083 at $10 \%$ level of significance. Its coefficient negative 0.7189293 shows that remaining other things constant a one percent increase in Ethiopian commercial banks lending interest rate will drop Ethiopian private commercial banks profitability with 0.7189293 percents. This might be happed from that if lending interest rate is higher and higher, the number of borrowers will reduced and sufficient amount of interest revenue will not be collected.

Foreign Exchange Rate

The $\mathrm{p}$ value of foreign exchange rate 0.057 is statistically significant at $10 \%$. The coefficient of foreign exchange rate negative 0.1762523 shows the relationship between foreign exchange rate and Ethiopian commercial banks profitability is indirect. From this result it is understood that the continuous currency/Ethiopian birr depreciation relative to U. S. dollar has a negative effect on Ethiopian private commercial banks profitability.

A study on determinants of bank profitability in Ukraine found that foreign exchange rate has a positive significant effect on income which could be explained by the ability of bank managers to anticipate exchange rate fluctuations [7]. Again, a study entitled determinants of commercial bank profitability conducted in Ethiopia proves the existence of positive or direct relationship between foreign exchange rate and profitability of Ethiopian banks [26]. The difference could happen as a result of those researchers use the direct quote of foreign exchange rate (home currency per unit of foreign currency).

\section{Conclusion}

The aim of this study was to investigate the factors affecting commercial banks profitability by using ten years unbalanced panel data covering from 2008 to 2017 in fourteen private commercial banks. For this purpose, both internal or bank specific and external or macroeconomic explanatory variables are incorporated.

From bank specific explanatory variables incorporated in this study bank size and capital adequacy were found to have a positive significant effect on Ethiopian private commercial banks profitability. Whereas, operation efficiency has a negative statistically significant effect on Ethiopian private commercial banks profitability.

In this study, the empirical finding shows all macroeconomic explanatory variables have a negative impact on Ethiopian private commercial banks profitability. From these variables only foreign exchange rate and lending interest rate are found statistically significant (though at $10 \%$ level of significance). Conversely, real GDP growth rate and inflation rate are insignificant with a higher $\mathrm{p}$ value. Therefore, it is possible to conclude that bank specific variables have more significant effect than macroeconomic variables on Ethiopian private commercial banks profitability.

\section{Recommendations}

Based on the finding of this study the following recommendations are forwarded to Ethiopian private commercial banks and regulatory bodies (like National Bank of Ethiopia).

Given the relationship between banks profitability and capital adequacy ratio is positive and highly significant, it is recommended to private commercial banks in Ethiopian to increase their stockholders equity thereby they can boost their profitability. The capital account can be improved though increasing paid up share capital (issuing additional share) and retaining banks earning.

From the finding of this study bank size is out to be positive and significant in the determination of Ethiopian private 
commercial banks profitability. Thus, Ethiopian privet commercial banks are recommended to increase their total asset that may be through; collecting deposit from customers, increasing shareholder's equity, or other equity and debt financing ways or may be through merger and acquisitions to enhance their profitability. Furthermore, it is recommended that privet commercial banks in Ethiopia should have an effective and efficient expense management practice.

\section{Appendix}

Table 4. Pearson Correlation Matrix.

\begin{tabular}{|c|c|c|c|c|c|c|c|c|c|}
\hline & CA & BS & LR & CR & OPE & INF & RGDPGR & FER & LIR \\
\hline $\mathrm{CA}$ & 1.0000 & & & & & & & & \\
\hline BS & -0.5632 & 1.0000 & & & & & & & \\
\hline LR & 0.0599 & -0.1828 & 1.0000 & & & & & & \\
\hline $\mathrm{CR}$ & 0.0195 & -0.0940 & -0.0544 & 1.0000 & & & & & \\
\hline OPE & 0.2044 & -0.3465 & 0.1484 & 0.0941 & 1.0000 & & & & \\
\hline INF & 0.0293 & -0.1058 & 0.0548 & -0.2612 & -0.0412 & 1.0000 & & & \\
\hline RGDPGR & 0.0166 & -0.2751 & 0.0217 & 0.1108 & -0.1754 & -0.0741 & 1.0000 & & \\
\hline FER & -0.0198 & -0.4203 & 0.3070 & 0.0364 & -0.0998 & 0.2734 & 0.5546 & 1.0000 & \\
\hline LIR & -0.0299 & 0.2292 & -0.1610 & -0.0407 & 0.1797 & -0.2379 & -0.6816 & -0.5409 & 1.0000 \\
\hline
\end{tabular}

Source: STATA 13 Output for Pearson Correlation Matrix.

Table 5. Hausman Test for Fixed Versus Random Effect Model.

\begin{tabular}{lllll}
\hline & Coefficients & & & \\
\cline { 2 - 5 } & (b) Fixed & (B) Random & (b-B) Difference & sqrt (diag(V_b-V_B)) \\
\hline CA & .3117226 & .2636062 & .0481164 & .0590332 \\
BS & 1.39825 & .5423508 & .8558992 & .4253643 \\
LR & .2209723 & .1928156 & .0281568 & .0632894 \\
CR & .0351296 & .0415015 & -.0063719 & .0068122 \\
OPE & -1.616984 & -1.621354 & .0043702 & .0420047 \\
LIR & -.7189293 & -.7456967 & .0267673 &. \\
INF & -.0154021 & -.0148889 & -.0005131 &. \\
RGDPGR & -.0224091 & -.066825 & .0444159 &. \\
FER & -.1762523 & -.2758206 & .0995683 & .0568207 \\
\hline
\end{tabular}

$\mathrm{b}=$ consistent under Ho and Ha; obtained from xtreg.

$\mathrm{B}=$ inconsistent under Ha, efficient under Ho; obtained from xtreg.

Test: Ho: difference in coefficients not systematic

$\operatorname{chi} 2(9)=(b-B)^{\prime}\left[\left(V_{-} b-V \_B\right)^{\wedge}(-1)\right](b-B)=39.31$

Prob $>$ chi $2=0.0000$.

(V_b-V_B is not positive definite).

Source: STATA 13 Output for Hausman Specification Test.

\section{References}

[1] Fentaw, F. L. (2012). Meta Analysis on the Determinants of Commercial Bank's Profitability: (A Conceptual Framework and Modeling). Europian Scientific Journal, 11, 323-351.

[2] Ani, W. U., Ugwunta, D. O., Ezeudu, I. J., \& Ugwuanyi, G. O. (2012). An empirical assessment of the determinants of bank profitability in Nigeria: Bank characteristics panel evidence. Journal of Accounting and Taxation, 4(3), 38-43.

[3] Athanasoglou, P. P., Brissimis, S. N., \& Delis, M. D. (2005). Bank specific, Industry specific and macroeconomic determinants of bank profitability. Greece.

[4] Bojaoui, R., \& Bouzgarrou, H. (2014). Determinants of Tunisian banks profitability. International journal of business and Finance Research, 8 (4), 121-131.

[5] Cameron, A., \& Trivedi, P. (2009). Micro econometrics using Stata, Stata Corp LP.
[6] Dani, S. (2014). Profitability Determinants of Indian banks Empirical study. International Journal of Advanced Research in Management and Social sciences, 3, 174-198.

[7] Davydenko, A. (2010). Determinants of bank profitability in Ukraine. Undergraduate Economic Review, 7 (1), 1-30.

[8] Dawood, U. (2014). Factors impacting profitability of commercial banks in Pakistan for the period of (2009-2012). International Journal of Scientific and Research Publications, 4 (3), 1-7.

[9] Elefachew, M., \& Rao, H. P. (2016). The impact of industrial diversification on Ethiopian banks' profitability. International Journal of Commerce and Management Research, 2 (10), 1317.

[10] Fortun News. (2015). Retrieved December 30, 2016, from Addis Fortun Web site.

[11] Francis, M. E. (2013). Determinants of Commercial Banks Profitability in Sub-Saharan Africa. International Journal of Economic and Finance, 5 (9), 134-147. 
[12] Gemechu, S. A. (2016). Determinants of Banks' Profitability Evidence from Banking Industry in Ethiopia. International Journal of Economics, Commerce and Management, IV (2), 442-463.

[13] Gujarati. (2004). Basic Econometrics (Fourth ed.).

[14] Habtamu, A. N. (2012). Determinants of Bank Profitability: An Empirical Study on Ethiopian Private Commercial Banks. Addis Ababa University, Addis Ababa, Ethiopia.

[15] Hoffmann, P. S. (2011). Determinants of the Profitability of the US Banking Industry. International Journal of Business and Social Science, 2 (22), 225-269.

[16] Islam, S., \& Nishiyama, S.-I. (2015). The determinants of bank profitability: dynamic panel evidence from South Asian countries. Sendai.

[17] Kokobe, A. S., \& Birhanu, N. D. (2015). Detreminants of Financial Performance of Commercial Banks in Ethiopia. Journal of Business Management and Economics, 3 (11), 3340.

[18] Kosmidou, K., Tanna, S., \& Pasiouras, F. (2012). Determinants of profitability of domestic UK commercial banks: panel evidence from the period 1995-2002.

[19] Majid Kabajeh, M. A., AL Nu'aimat, S. M., \& Dahmash, N. F. (2012). The Relationship between the ROA, ROE and ROI Ratios with Jordanian Insurance Public Companies Market Share Prices. International Journal of Humanities and Social Science, 2, 115-120.
[20] National Bank of Ethiopia. (2016/17). Annual report.

[21] Obamuyi, T. M. (2013). Determinants of Banks' Profitability in a Developing Economy: Evidence from Nigeria. Organizations and Markets in Emerging Econmies, 4 (2(8)), 97-111.

[22] Ponce, A. T. (2009). What Determines the Profitability of Banks? Evidence from Spain. Pablo de Olavide University, Department of Business Administration.

[23] Rao, R. M., \& Tekeste, L. B. (2012). Determinants of Profitability of Commercial Banks in a Developing Country Evidence from Ethiopia. International Journal of Accounting and Financial Management research, 2 (3), 1-20.

[24] Roman, A., \& Danuletiu, A. E. (2013). An Empirical Analysis of the Determinants of Bank Profitability in Romania. Annales Universitatis Appulensis Series Oeconomica, 580-593.

[25] Said, R. M., \& Tumin, M. H. (2011). Performance and Financial Ratios of Commercial Banks in Malaysia and China. International Review of Business Research Paper, 7, 157-169.

[26] Samuel, A. (2015). Determinants of Commercial Bank Profitability: The case of Ethiopian Commercial Banks. Msc Thesis, Addis Ababa University, Addis Ababa, Ethiopia.

[27] Tsalkitzidis, K. (2011). Determinants of Banks Profitability in Greece and Balkans' before and during Financial Crisis.

[28] Wooldridge, J. M. (2002). Introductory Econometrics: A Modern Approach (2nd ed.). 